\title{
SYNTHETIC ANTIMICROBIAL AGENT AND ANTIMICROBIAL FABRICS: PROGRESS AND CHALLENGES
}

\author{
NORASHIKIN MAT ZAIN ${ }^{*}$, John OLABOdE AKINDOYO ${ }^{1,2}$ \\ AND MOHAMmad Dalour Hossen BeG ${ }^{1}$ \\ ${ }^{1}$ Faculty of Chemical and Natural Resources Engineering, Universiti Malaysia Pahang, \\ Lebuhraya Tun Razak 26300 Gambang Kuantan, Pahang, Malaysia. \\ ${ }^{2}$ School of Materials \& Mineral Resources Engineering,Engineering Campus, Universiti Sains \\ Malaysia,14300 Nibong Tebal, Pulau Pinang, Malaysia. \\ "Corresponding author: shikin@ump.edu.my
}

(Received: 26 ${ }^{\text {th }}$ April 2018; Accepted: 25 th Sept 2018; Published on-line: $1^{\text {st }}$ Dec 2018) https://doi.org/10.31436/iiumej.v19i2.929

\begin{abstract}
Recently, there is a strengthening requirement for antimicrobial fabrics that are resistant to pathogens, offer greater hygiene, and are protective in an active lifestyle. Synthetic compounds have been applied to impart antimicrobial properties to the fabrics. In this paper, synthetic antimicrobial agents, namely quaternary ammonium compounds (QACs), polyhexamethylene biguanide (PHMB), triclosan, and $N$-halamine are discussed along with their mechanisms of action. Research has been done on synthetic antimicrobial treatment of fabrics; the tested microorganisms used to determine their efficiency and durability are summarized. It is also found that although synthetic antimicrobial agents have excellent strength to kill the microorganisms, some of these antimicrobial agents are harmful and have adverse effects on the environment, safety, and health. Identification of these problems will provide future challenges to overcome and improve the techniques used for antimicrobial treatment of the fabrics. Based on the infromation presented herein, it is recommended that subsequent studies should consider the use of antimicrobial agents that are either obtained from plant sources or from microorganisms. On the other hand, nanotechnlogy should be explored for production of antimicrobial agents in further studies based on its potential to facilitate the production of environmentally benign antimicrobial agents.
\end{abstract}

ABSTRAK: Kebelakangan ini, permintaan terhadap fabrik antimikrobial bagi mencegah jangkitan patogen, penjagaan kebersihan dan perlindungan bagi gaya hidup yang aktif semakin meningkat. Sebatian sintetik telah diguna pakai bagi menambah sifat antimikrobial pada fabrik. Di dalam artikel ini, agen antimikrob sintetik yang dinamakan sebagai sebatian ammonium kuater (QAC), polyhexamethylene biguanide (PHMB), triclosan dan N-halamine serta mekanisma tindak balasnya telah dibincangkan. Penyelidikan telah dijalankan terhadap fabrik yang dirawat menggunakan agen antimikrob sintetik. Mikroorganisma yang digunakan bagi menentukan kecekapan dan daya tahan turut diringkaskan. Keputusan menunjukkan agen antimikrobial sintetik mempunyai tindak balas yang sangat baik untuk membunuh mikroorganisma, namun sebahagian agen antimikrobial ini berbahaya dan mempunyai kesan buruk terhadap alam sekitar, keselamatan dan kesihatan. Melalui kaedah kenal pasti masalah, ia dapat memberi solusi dan membaiki teknik rawatan antimikrobial pada fabrik pada masa 
hadapan. Hasil keputusan dan perbincangan menunjukkan kajian seterusnya harus menimbang penggunaan agen antimikrobial yang diperoleh dari sumber tumbuhan. Selain itu, nanoteknologi harus diterokai bagi pengeluaran agen antimikrobial berdasarkan potensinya yang mesra alam.

KEYWORDS: antimicrobial; fabrics; microorganisms; efficiency; synthetic antimicrobial agent

\section{INTRODUCTION}

The use of antimicrobial agents on fabrics dates back to ancient times when the Egyptians used spices and herbs to preserve mummy wrappings [1]. The first antimicrobial fabric was developed by Lister in 1867 [2]. Today there is global suffering due to some serious illnesses caused by harmful microorganisms [3]. Interestingly, antimicrobial fabrics have been used in different applications such as pharmaceutical, medical, engineering, agricultural, and food industries [4]. Besides that, consumers' attitude towards hygiene and active lifestyle has created a rapidly increasing demand for a wide use of antimicrobial fabrics [5]. It is well known that fabrics in contact with infected skin can serve as a carrier for fungi and bacteria, thereby facilitating their propagation. Therefore, there is the need for fabrics with potent antimicrobial properties. In essence, explorations of antimicrobial fabrics for their antibacterial and antifungal activities are required to assess the clinical potential of fabrics for odor, skin problem prevention and to avoid microorganisms' cross contamination [6]. So, there is a growing worldwide interest in the use of antimicrobial fabrics [7,8]. This would help to curtail the challenges hitherto associated with spread and propagation of microorganisms through fabrics.

A microorganism is an organism that is microscopic and which can only be seen under a microscope [9]. A right temperature, moisture, dust, and receptive surface offer perfect environments for microorganism growth on fabric surface [10]. In good conditions, bacteria and fungi can propagate within a very short time. These microorganisms can obtain sufficient food through perspiration and other body secretions, skin particles, and fats [11]. Although microorganisms can be beneficial in some ways, they can also be seriously unsafe to both fabrics and humans. In fact, it has been observed that the microorganisms that may be found on fabrics can become disease causatives to those wearing such fabrics. They can also lead to decay of fabric quality; for example, bacteria such as Staphylococcus aureus on the underwear causes odour, Escherichia coli causes odour and ulcers on the skin, and fungi such as Aspergillus niger weakens and decolorizes clothing [12]. Trouser legs and pockets can habour Bacillus, Staphylococcus epidermis and Micrococcus. Clothing in the inguinal and perineal areas soiled by urine often stimulates the growth of Brevibacterium ammoniagenes, $E$. coli, and Proteus mirabilis, causing diaper rash and infections [13]. It is noteworthy that these pathogens cannot be eliminated by simple laundering. Reportedly, fungi, Trychophyton rubrum, which is the causal organism of athlete's foot, survives laundering at low temperatures around $30^{\circ} \mathrm{C}$ and after washing, it was found that this fungi had spread to the other fabrics [14].

Other potential adverse effects of microorganisms on fabrics include the possible loss of functional properties like elasticity and tensile strength as well as deterioration of the fabrics, especially cotton and wool [15]. Deterioration of fabrics is usually caused by filamentous fungi, with only a few being caused by bacteria. These microorganisms can cause several problems to humans, from unpleasant odor to physical irritation, allergy, toxic responses, infection, and 
dangerous diseases [11]. Considering these undesirable phenomenon, scientists continue to search for antimicrobial agents that can help to mitigate the problems [9].

The effectiveness of fabrics to destroy microorganisms is determined based on the antibacterial or antifungal activity by measuring the colonies of the microorganisms before and after the treatment. Durability of the fabrics will be tested by measuring the antibacterial or antifungal activities against repeated laundering. It is usually challenging work to obtain fabrics that have both high antibacterial/antifungal activity as well as high durability to laundering. This is coupled with the fact that environmental, health, and safety aspects of the use of antimicrobial agents must be considered $[4,16]$. In fact, the use of some antimicrobial agents has been discontinued because of their harmful effects to the human body and the environment $[17,18]$.

To date, a number of synthetic chemicals have been applied to impart antimicrobial properties unto the fabrics. Almost all synthetic antimicrobial agents used on fabrics are biocides [4]. To the best of the authors' knowledge, there is no summarized report on the beneficial and adverse effect of synthetic antimicrobial agents on fabrics. Therefore, this paper presents a summary of synthetic antimicrobial treatment of fabrics, their efficiency and durability as tested on different types of microorganisms, their advantages, and the adverse effect of application of these agents. Progress on antimicrobial fabrics is also provided, as well as recommendations for future research.

\section{EMERGENCE OF ANTIMICROBIAL AGENTS}

The general public has become more aware of the effects of antimicrobial agents on health. This has largely contributed to the increasing demand for antimicrobial agents in different fields [19]. It is well known that fabrics produced from natural fibers can serve as a good medium for the proliferation of pathogenic microorganisms due to their high moisture retaining ability and wide large surface area [20,21]. In addition, temperature and nutrients such as dead skin cells, stains, and secretions such as sweat on the fabrics can facilitate the rapid growth of different bacteria and fungi [10]. Likewise, the presence of microorganisms can degenerate the fabrics in form of colour stains, unpleasant odours, discoloration, higher tendency for cross contamination, or fabric deterioration [15]. It can also result in allergic responses in the fabric users as well as other potential health related issues. These make it necessary to prevent possible undesirable occurrences through the use of antimicrobial agents [10,19].

\section{SYNTHETIC ANTIMICROBIAL AGENTS}

Microorganisms generally have outer cell walls that are made up of polysaccharides. This polysaccharide wall is responsible for maintaining the cellular integrity of the cell components as well as protecting the cell from external factors [22]. Next to the polysaccharide wall is a membrane that hosts the intracellular components alongside several enzymes, as well as nucleic acids. All the genetic details of the organism are stored in the nucleic acids whereas the enzymes help to facilitate different chemical reactions within the cell [22]. All these components need to be properly functional in order to sustain the growth and survival of the organism. Therefore, antimicrobial agents work by attacking and damaging the cell wall, or disrupting the normal 
functionalities of the organism's cell [22]. Although there could be different classifications of antimicrobial agents, it is generally agreed that they can be grouped as either biocides or biostats. Biocides are substances that kill microorganisms while biostats function by inhibiting the growth and proliferation of microorganisms [4], and their mechanisms of action are closely related to the amount of active substances imparted unto the antimicrobial fabric [4].

Based on literature, the most commonly used synthetic antimicrobial agents for fabrics are quaternary ammonium compounds (QACs), polyhexamethylene biguanide (PHMB), triclosan and $N$-halamines. The mechanism of action of these four classes of antimicrobial agents have been presented in this section as representative antimicrobial agents for fabrics.

\subsection{Quaternary Ammonium Compounds (QACs)}

Quaternary ammonium compounds (QACs) are molecules with at least one hydrophobic hydrocarbon chain connected to a positively charged nitrogen atom as shown in Fig. 1. The other alkyl or aryl groups are frequently short chain substituents such as methyl or benzyl groups [23].

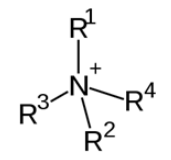

Fig. 1: Representative structure of quaternary ammonium compounds (QACs).

QACs are outstanding antimicrobial agents [24]. The antimicrobial activity of QACs ensues from both ionic and hydrophobic connections between the QAC and components of the microbial cell wall which often leads to cell death or malfunction in cellular processes [25]. Factors such as charge density, molecular size, and molecular mobility determines the ability of a QAC to bind to the bacterial cell wall and/or cell membrane, thereby interrupting its normal function [26]. Usually, QACs would attack the phospholipid components of the membrane, by irreversibly binding to them. This would lead to impaired membrane permeability, causing membrane deformation, leakage of low-molecular-weight intracellular material, and disruption of the proton motive force [27].

\subsection{Polyhexamethylene Biguanide}

The structure of polyhexamethylene biguanide (PHMB) is shown in Fig. 2. PHMB is another antimicrobial agent which is mainly used in food, medicine, water industries, and others.

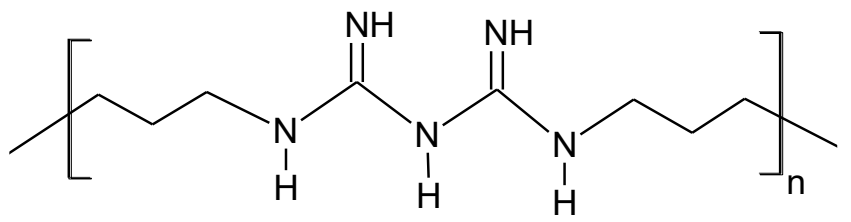

Fig. 2: Structure of polyhexamethylene biguanide.

PHMB has been applied onto fabrics to avoid microbial growth. PHMB is a water-soluble, positively charged polymer, with broad-spectrum antimicrobial effects toward Gram-positive 
and Gram-negative bacteria, fungi, and yeast $[28,29]$. Its composition is a mixture of polymeric biguanides of structure $\left[\left(\mathrm{CH}_{2}\right)_{6} \text {.NH.C }(=\mathrm{NH}) \text {.NH.C.NH- }\right]_{n}$, where $n$ can vary from 2 to 40, resulting in a molecular mass range from 400 to 8000 [30]. The antibacterial action of PHMB upon E. coli has been studied and it is found that growth inhibition and antibacterial activity increased with increasing levels of PHMB-polymerization [31]. In another vein, studies have reported that $\mathrm{PHMB}$, which at a physiological $\mathrm{pH}$ acts like a polycation, only interacts with negatively charged, acidic phospholipids, whereas neutral phospholipids were not affected [32]. This concept describes both the broad spectrum antimicrobial activity and the low mammalian toxicity of PHMB [33]. Generally, the antibacterial and antifungal activity of PHMB is based on its ability to induce phospholipid phase separation and cause loss of membrane function in bacteria or yeast [34].

\subsection{Triclosan}

Another notable antimicrobial agent is triclosan (5-chloro-2-(2,4-dichlorophenoxy)phenol). Triclosan (5-chloro-2-(2,4-dichlorophenoxy)-phenol) (Fig. 3) is a stable, chlorinated phenolic and liphophilic compound [35-37]. It is a potent antibacterial and antifungal compound that is generally used in personal care products, plastics, and fabrics [38]. Triclosan acts as a site directed, very potent enzyme inhibitor by mimicking its natural substrate [39]. It has hydroxyl-halogenated derivate of two phenolic groups connected by various bridges, and is more effective against Gram-positive bacteria than Gram-negative bacteria [40]. Triclosan is fairly insoluble in aqueous solutions, unless the $\mathrm{pH}$ is alkaline, and readily soluble in most organic solvents. It is chemically stable and can be heated up to $200^{\circ} \mathrm{C}$ for up to $2 \mathrm{~h}$ [41]. Triclosan acts on microbial growth generally by inhibiting fatty acid biosynthesis through blocking of lipid biosynthesis in addition to acting together with amino acid residues of the enzyme-active site within a membrane [41].<smiles>Oc1cc(Cl)ccc1Oc1ccc(Cl)cc1Cl</smiles>

Fig. 3: Structure of triclosan

\section{4 $N$-halamines}

A group of compounds containing one or more nitrogen-halogen covalent bond, known as $\mathrm{N}$-halamine have also been reported to exhibit antimicrobial properties [42]. These compounds are formed by the halogenation of imide, amide, or amine groups [43]. Compared with inorganic halogens (e.g., chlorine or bromine), organic $N$-halamines are more stable, less corrosive, and have much less tendency to generate halogenated hydrocarbons [44]. The bactericidal action of $N$-halamines is believed to be a chemical reaction involving the direct transfer of positive halogens from the $N$-halamines to appropriate receptors in the bacterial cells [45]. That is, in $N$-halamine structures with a general formula of $\mathrm{N}\left(R_{1} R_{2}\right)-X$ where $(X=\mathrm{Cl}$ or $\mathrm{Br}$ ), the strength of the $\mathrm{N}-X$ bond is significantly influenced by $R_{1}$ and $R_{2}$. If $R_{1}$ and $R_{2}$ are electron-donating groups (in the case of amine $N$-halamines), they will tend to destabilize any developing negative charge on $\mathrm{N}$ as $X^{+}$leaves the molecule and the stability will increase, thereby decreasing the antimicrobial properties [46]. Similarly, electron-withdrawing groups 
attached to nitrogen (in the case of amide and imide $N$-halamines) would decrease the stability but increase the antimicrobial function [43]. The oxidative halogen is transferred to a microorganism through direct contact, the rate of which depends upon the strength of the $N-X$ bond, which in turn is related to the structure of the $N$-halamine molecule [47].

\section{ADVANTAGES AND DISADVANTAGES OF SYNTHETIC ANTIMICROBIAL AGENTS}

Based on the different degree of problems that can possibly be associated with the use of antimicrobial agents, researchers have noted that an ideal antimicrobial agent should combine different salient properties [48]. It should not present adverse toxicity to humans, it should exhibit a wide spectrum of antimicrobial potency, it should not lead to damage of the inherent fabric properties, it should be able to withstand fabric production procedures, and the antimicrobial durability should be stable throughout the fabric's use life [10].

The importance of antimicrobial agents and antimicrobial fabrics cannot be gainsaid. However, is it generally required that their durability and benefits should not trigger subsequent potential risks to humans and the environment. Therefore, safety assessment of these materials is always necessary. This can be possible by equally assessing the benefits and risks associated with the use of any antimicrobial agent or antimicrobial fabric [48].

\subsection{Advantages of Synthetic Antimicrobial Agents}

The ultimate reason for the use of antimicrobial agents in fabrics is to curtail infections arising from pathogenic microorganisms [49]. It is well known that the transmission of infectious diseases is more rampant in hospitals and other locations related to public health. This can be prevented or reduced if antimicrobial fabrics are used by workers instead of normal fabrics [50]. The antimicrobial agents can help to protect antimicrobial fabric users from pathogens on one hand as well as sustaining the quality of the fabric on the other hand $[4,48]$. Different synthetic antimicrobial agents have been tested on fabrics. They have powerful antimicrobial activity, as indicated by their effectiveness and durability. The benefits of using synthetic antimicrobial agents are presented in Table 1.

\subsection{Disadvantages of Synthetic Antimicrobial Agents}

Several antimicrobial agents have been applied to fabrics as can be seen from the very many articles on the subject [49,56-61]. In order to facilitate the good performance of these antimicrobial agents, different chemical are often used [56]. These include organometallics, slow iodine-releasing substances (iodo-phors), inorganic salts, anionic group bearing heterocyclics, phenols, thiophenols, urea and its compounds, nitro compounds, amines, and derivatives of formaldehyde and others $[15,19,20,56]$. However, reports show that a large proportion of these chemicals do not easily degrade in nature and poses high toxicity to humans $[49,56]$. On the other hand, those that easily decompose may constitute a nuisance to the environment $[62,63]$. 
Table 1: The benefits of using synthetic antimicrobial agents

\begin{tabular}{llc}
\hline $\begin{array}{l}\text { Synthetic } \\
\text { Antimicrobial Agent }\end{array}$ & Benefits & Reference \\
\hline QACs & $\begin{array}{l}\text { Strong antimicrobial agent and have a broad } \\
\text { spectrum of antimicrobial activity. }\end{array}$ & {$[51]$} \\
PHMB & $\begin{array}{l}\text { Highly effective antimicrobial agents and have } \\
\text { low toxicity to human cells. }\end{array}$ & {$[52,53]$} \\
Triclosan & $\begin{array}{l}\text { It has demonstrated immediate, persistent, } \\
\text { broad-spectrum antimicrobial effectiveness } \\
\text { against bacteria, fungi and virus. } \\
N \text {-halamine compounds }\end{array}$ & {$\left[\begin{array}{l}\text { Capable of providing fast and total kill against a } \\
\text { wide range of microorganisms without causing } \\
\text { resistance from microorganisms and can be used } \\
\text { for long term disinfection. }\end{array}\right.$} \\
\hline
\end{tabular}

Therefore, it is established that although synthetic antimicrobial agents can be very effective against a wide range of microorganisms as well as have durable effect on fabrics, there are causes for concern due to health hazards and environmental pollution [64-66]. This is because most of these agents have toxic effects and cannot easily degrade in nature $[56,67,68]$. Among the four classes of antimicrobial agents reported herein, the adverse effects of PHMB and $N$-halamines are mild and possibly negligible. A summary of the main disadvantages of the two other classes (triclosan and QACs) are highlighted in Table 2.

\section{CHALLENGES IN THE PRODUCTION OF ANTIMICROBIAL FABRICS}

One major challenges faced with the use of antimicrobial agents is how to sustain the antimicrobial durability of the modified fabric [10]. This is due to the fact that during its use life, fabrics would normally be exposed to several actions such as washing, drying, wear, ironing, and so on. Therefore, it is important to assess the antimicrobial durability of modified fabrics. Unfortunately, assessment of durability is a complex and time-consuming task compared with normal antimicrobial tests [10]. This is a major challenge to assessment of antimicrobial reliability of modified fabrics. In general, durability of antimicrobial fabrics can be broadly classified as either temporary antimicrobial fabric or durable antimicrobial fabric. Although temporary antimicrobial fabric is easier to produce, their antimicrobial potency is often lost during laundering processes [50].

This is because there is a close relationship between antimicrobial properties and concentration of active substances
in the antimicrobial fabric. Thus laundering activities, as well as leaching of active components into the
environment, can cause the concentration of active components to drop below the level required for proper actions.
One major problem associated with this is that it can lead to antimicrobial resistance [4]. In order to ensure
antimicrobial durability through conventional techniques, several steps are usually involved such as neutralization,
functionalization, curing, and so on. These steps are very expensive, time demanding, and most often not
environmentally friendly [67]. In addition, they often lead to decreases in properties of the
antimicrobial fabric such as softness, appearance, and tensile and abrasive properties [67]. These
have often posed serious challenges to production of durable antimicrobial fabrics. 


\subsection{Temporary Antimicrobial Fabrics}

Temporary antimicrobial fabrics are easy to produce because they do not demand rigorous processes. However, their antimicrobial potency is easily lost after washing. As such, temporary antimicrobial fabrics generally refer to the group of fabrics that tend to lose their antimicrobial performance after only a few washing cycles. These antimicrobial fabrics are generally undesirable, which makes it a less important subject of discussion [50].

\subsection{Durable Antimicrobial Fabrics}

One of the major requirements of an ideal antimicrobial fabric is durability. Hence, it is often necessary that the fabric should manifest good durability throughout its use life. However, this is usually a grave challenge for researchers due to the fact that fabrics are normally subjected to several actions including washing, wear, ironing, and drying during the period of their use [10]. In addition, considering the complications surrounding the evaluation of durability, only few studies have focused on durability compared to the several studies available on antimicrobial activity [10].

More often than not, washing durability is one of the notable parameters used for evaluating the antimicrobial performance of fabrics. This denotes the quantity of the antimicrobial potency which is able to withstand repeated washing processes. Notably, a group of $N$-halamine compounds have been reported suitable to provide durable antimicrobial properties onto fabrics. The antimicrobial properties of these compounds are said to be highly durable and even rechargeable [50]. In fact, they are said to be non-toxic [83], and the mode of their action is through oxidation of amino acids leading to inactivation of the microorganisms' cells within a short period of contact $[83,84]$.

Interestingly, in a recent study, novel antimicrobial cotton fabric with desirable durability was prepared through a process that involves the physical absorption, followed by chemical bonding of modified polyhexamethylene guanidine (PHMG) onto the cotton surface [85]. In their study, they assessed the antimicrobial performance of the modified cotton fabrics through the shaking flask method whereas laundering durability was used to evaluate the non-leaching properties [85]. It was inferred from the research that the interaction between the modified fabric and molecules of the antimicrobial agent plays notable roles in determining the durability of the fabric [85]. 
Table 2: Disadvantages of using synthetic antimicrobial agent

\begin{tabular}{|c|c|c|}
\hline Effects & Explanation & Reference \\
\hline \multirow{3}{*}{$\begin{array}{l}\text { Ecotoxicity and } \\
\text { environmental } \\
\text { effect }\end{array}$} & Triclosan is a widely employed antimicrobial agent that has been found as a contaminant in rivers and lakes & {$[69,70]$} \\
\hline & Exposure to sunlight causes the breakdown of triclosan and the formation of toxic polychlorinated dioxins & {$[22]$} \\
\hline & $\begin{array}{l}\text { QACs also have toxicity effect against the environment, and their effects are short lived because of the difficulty of } \\
\text { controlling their rate of diffusion }\end{array}$ & {$[71,72]$} \\
\hline \multirow{3}{*}{$\begin{array}{l}\text { Skin irritation } \\
\text { and effect of } \\
\text { exposure }\end{array}$} & Wearing treated fabrics with triclosan can lead to sensitization and skin irritation such as itching & {$[22,73]$} \\
\hline & Triclosan has been detected in human breast milk, at levels ranging from 0 to $2100 \mathrm{lg} / \mathrm{kg}$ lipid, in serum and in urine & {$[37,74-77]$} \\
\hline & Laboratory studies have documented that triclosan disrupts thyroid systems in rats and frogs & {$[38,78,79]$} \\
\hline \multirow{4}{*}{$\begin{array}{l}\text { Bacteria } \\
\text { resistance }\end{array}$} & Wearing treated fabrics with some synthetic antimicrobial; agents in a continuous manner can cause bacteria resistance & [22] \\
\hline & $\begin{array}{l}\text { The release of QACs from the fabrics into the surroundings could have destructive impacts on living organisms in water } \\
\text { because they can affect susceptible bacteria, thereby potentially selecting resistant bacteria }\end{array}$ & {$[80]$} \\
\hline & $\begin{array}{l}\text { Moreover, it was recently reported that the presence of QACs in QAC-polluted environments contributes to the induction } \\
\text { of antibiotic resistance of bacteria which is currently an alarming human health concern }\end{array}$ & [81] \\
\hline & $\begin{array}{l}\text { Furthermore, triclosan blocks bacterial lipid biosynthesis which leads to concern for possible development of bacterial } \\
\text { resistance }\end{array}$ & {$[39,82]$} \\
\hline
\end{tabular}




\section{SYNTHETIC ANTIMICROBIAL FABRIC TREATMENT}

To date, a number of synthetic antimicrobial agents have been applied to impart antimicrobial properties to the fabrics. The summary of different types of synthetic antimicrobial agents tested on different types of fabrics, the tested microorganisms, efficiency, and durability are presented in Table 3 . It can be inferred that cotton and wool impregnated with QACs exhibited excellent antimicrobial activity. The cotton fabrics with QACs show antimicrobial activity even after 30 laundry cycles. However, nylon impregnated with QACs shows low durability against laundering. On the other hand, PHMB shows low antimicrobial activity on cotton fabrics. In contrast, non-woven fabrics and cotton treated with triclosan displayed good antimicrobial activity. Notably, knitted cotton displayed good antimicrobial activity even after 50 laundry cycles. In another vein, cotton fabrics impregnated with $N$ halamine show less antimicrobial activity. However, the antimicrobial resistance of the cotton with N-halamine is generable by regular laundry exposure to chlorine bleach and can withstand more than 50 standard machine washes without deterioration. In summary, QACs exhibit excellent antimicrobial activity against different types of bacteria while triclosan and $N$ halamine exhibit excellent durability against laundering. However, PBHB impregnated fabric shows less effectiveness of antimicrobial activity.

\section{FUTURE TRENDS IN ANTIMICROBIAL FABRIC}

It is well established that most synthetic antimicrobial agents are obtained from petrochemical-based sources involving the use of different hazardous organic solvents that pose threats to both human and environmental health [99-102]. It is also well known that antimicrobial potency is not the only important property in antimicrobial fabrics, but there is a need to consider environmental and human health during their use [4]. Therefore, high importance is being placed on, and attention is recently being concerted towards, the use of environmentally friendly, non-toxic, antimicrobial agents [99]. The main benefit of this approach is that natural antimicrobial agents do not elicit any observable health related problems both at production stage and during the use life of the antimicrobial fabrics [99, 103]. However, there are concerns about the antimicrobial durability of naturally modified antimicrobial fabrics.

On a general note, antimicrobial fabrics may be obtained through chemical or physical incorporation of antimicrobial agents onto the fabrics [50]. Chemical incorporation of antimicrobial agents onto fabrics is often a good way to ensure lasting durability of the antimicrobial fabric. However, it is very important that the antimicrobial agents should be incorporated onto the fabric through covalent bond [4,50]. This would help to maintain the integrity of the environment. The antimicrobial fabrics produced through this means have been observed to be environment due to non-release of toxic substances into the environment, a condition common with conventional antimicrobial fabrics [4].

The new trend in antimicrobial fabrics is therefore focused on the use of products that contain covalently bound active agents unlike the leaching-prone conventional antimicrobial fabrics. Initially, use of nanoparticles and nanocomposites was thought to be a way forward. These inorganic nanoparticles are believed to be capable of opening new modern opportunities 
for antimicrobial fabrics [67,104]. In fact, there is evidence for the safety of this approach. However, recent public awareness on health care has increased the concerns on possible side effects of new technologies on human and environmental health [67].

Progress in research has led to the use of natural bioactive antimicrobial agents of plant origin $[4,67]$. These types of antimicrobial fabrics have been observed to be non-toxic, safe, and human and environmentally friendly [4]. Therefore, in order to facilitate antimicrobial durability of naturally derived antimicrobial fabrics, series of methods are being used to impart the active agents onto the fabric [105-107].

In a recent study, natural herbal extracts from Azadirachta indica was used to impart antimicrobial properties onto fabrics without the incorporation of any additives [108]. Antimicrobial potency of the treated fabrics was tested against Escherichia coli and Staphylococcus aureus. It was reported that treated fabrics did not only manifest desirable antimicrobial property, but it also revealed good washing durability as well as improved UVresistance properties. The notable active compounds present in the natural nanoparticle extract of the leaves includes nimbolide, mahmoodin, nimbidin, isomargolonone, margolonone, and margolone [108]. All of these have been reported to contribute to the antimicrobial properties of this extract [108]. In another study, antimicrobial fabrics were produced from natural extracts from Nerium oleander, Trigonella foenum graecum, and Curcuma longa. Phytochemical analysis of the extract obtained from Nerium oleander showed that the extract contains different compounds, which are mainly alkaloids, flavonins, proteins, saponins, tannins, and other aromatic acids [106]. The extract from Trigonella foenum graecum contains alkaloids, flavonins, proteins, saponins, tannins, aromatic acids and reducing sugars. On the other hand, analysis of the extract from Curcuma longa contains alkaloids, flavonins, terpenoids, plobatinins, saponins, tannins, and other aromatic acids [109]. Interestingly, it was found that the antimicrobial fabric obtained from these extracts manifested efficient anitimicrobial activity against different tested pathogenic microbes [109]. Similarly, among other progressive studies, there has been a report on possible establishment of a new generation of environmentally compliant antimicrobial fabrics based on natural extracts from Polygonum cuspidatum, namely resveratrol (Res) [110]. All these studies point to the fact that researchers are turning towards the possibility of replacing synthetic chemicals based on antimicrobial agents with more naturally-based products. 
Table 3: Studies of synthetic antimicrobial agents used for the development of antimicrobial fabrics and efficiency towards microorganisms

\begin{tabular}{|c|c|c|c|c|c|}
\hline Biocide & Fabric & $\begin{array}{c}\text { Tested } \\
\text { Microorganism } \\
\end{array}$ & Effectiveness & Durability & Reference \\
\hline \multirow[t]{5}{*}{$\begin{array}{l}\text { Quaternary } \\
\text { ammonium } \\
\text { compounds } \\
\text { (QAC)s }\end{array}$} & Cotton & Staphylococcus aureus & $\begin{array}{l}\text { The treated fabrics displayed very } \\
\text { effective antimicrobial activity showing } \\
99.9 \% \text { of reduction in the number of } \\
\text { bacteria }\end{array}$ & NA & {$[86]$} \\
\hline & Wool & $\begin{array}{l}\text { Staphylococcus aureus } \\
\text { Bacillus pumilus }\end{array}$ & $\begin{array}{l}\text { The wool samples showed good } \\
\text { antimicrobial activity }\end{array}$ & NA & {$[87]$} \\
\hline & Cotton & $\begin{array}{l}\text { Staphylococcus aureus } \\
\text { Escherichia coli }\end{array}$ & $\begin{array}{l}\text { When the concentration of antimicrobial } \\
\text { agent exceeded } 70 \text { ppm, the } \\
\text { antimicrobial activity increased to more } \\
\text { than } 99.99 \% \text { for both bacteria }\end{array}$ & $\begin{array}{l}\text { Even after } 30 \text { cycles of washing, the } \\
\text { antimicrobial activity of the cotton } \\
\text { fabrics remained at a high level }\end{array}$ & {$[88]$} \\
\hline & Nylon & Escherichia coli & $\begin{array}{l}\text { The fabrics treated with more than } 4 \% \\
\text { quaternary ammonium salt showed much } \\
\text { better antimicrobial activity with results } \\
\text { of } 90 \% \text { bacterial reduction }\end{array}$ & $\begin{array}{l}\text { The fabric treated in } 2 \% \text { salt solution } \\
\text { started to lose the function after six } \\
\text { washes and showed less than } 90 \% \\
\text { potency on } E \text {. coli. It continued to } \\
\text { deteriorate after eight washes, and } \\
\text { finally became non-antimicrobial after } \\
\text { ten washes }\end{array}$ & [89] \\
\hline & Wool & Escherichia coli & $\begin{array}{l}\text { The treated fabrics shows excellent } \\
\text { antimicrobial functions }\end{array}$ & $\begin{array}{l}\text { After } 10 \text { times of washing, the treated } \\
\text { fabrics could still provide about } 70 \% \\
\text { of antimicrobial activity }\end{array}$ & {$[90]$} \\
\hline $\begin{array}{l}\text { Polyhexamethylene } \\
\text { biguanide } \\
\text { (PHMB) }\end{array}$ & Cotton & Staphylococcus aureus & $\begin{array}{l}\text { As increasing quantities of PHMB were } \\
\text { applied to cotton, bacterial growth on the } \\
\text { cotton reduced until there were no } \\
\text { growth at ideal concentrations }\end{array}$ & NA & {$[91]$} \\
\hline
\end{tabular}


Table 3: Continued

\begin{tabular}{|c|c|c|c|c|c|}
\hline Biocide & Fabric & $\begin{array}{c}\text { Tested } \\
\text { Microorganism } \\
\end{array}$ & Effectiveness & Durability & Reference \\
\hline \multirow[t]{4}{*}{ Triclosan } & $\begin{array}{l}\text { Non-woven } \\
\text { fabrics }\end{array}$ & $\begin{array}{l}\text { Staphylococcus aureus } \\
\text { Escherichia coli }\end{array}$ & $\begin{array}{l}\text { Microbiological tests indicated the high } \\
\text { antimicrobial activity of the Triclosan- } \\
\text { loaded microspheres against both } \\
\text { microorganisms }\end{array}$ & NA & {$[92]$} \\
\hline & Cotton & Escherichia coli & $\begin{array}{l}\text { When the triclosan concentration was } \\
\text { increased from } 3 \text { to } 5 \mathrm{wt} \% \text { in the film it } \\
\text { inhibited bacterial growth }\end{array}$ & NA & [93] \\
\hline & Cotton & $\begin{array}{l}\text { Staphylococcus aureus } \\
\text { ATCC } 6538 \\
\text { Escherichia coli ATCC } \\
35218\end{array}$ & $\begin{array}{l}\text { Antimicrobial activity decreased } \\
\text { somewhat after the use of polycarboxylic } \\
\text { acid and triclosan. It caused a change in } \\
\text { the pH level of the solution from basic to } \\
\text { acidic and affected the mechanism of } \\
\text { triclosan inhibition }\end{array}$ & $\begin{array}{l}\text { Adding polycarboxylic acids to the } \\
\text { fabrics containing triclosan enhanced } \\
\text { the durability against laundering }\end{array}$ & {$[40]$} \\
\hline & Knitted cotton & $\begin{array}{l}\text { Staphylococcus aureus } \\
\text { Escherichia coli }\end{array}$ & $\begin{array}{l}\text { The antimicrobial properties of raw } \\
\text { fabrics was significantly increased after } \\
\text { triclosan treatment and it was found to be } \\
\text { more effective against } S \text {. aureus than } E \text {. } \\
\text { coli }\end{array}$ & $\begin{array}{l}\text { The antimicrobial resistant of the } \\
\text { fabrics can withstand up to } 50 \text { laundry } \\
\text { cycles }\end{array}$ & {$[41]$} \\
\hline \multirow[t]{2}{*}{$\begin{array}{l}N \text {-halamine } \\
\text { compounds }\end{array}$} & $\begin{array}{l}\text { Cotton and } \\
\text { cotton blend } \\
\text { fabrics }\end{array}$ & Staphylococcus aureus & $\begin{array}{l}\text { Test results show uniformly high } \\
\text { antimicrobial activity on both pure cotton } \\
\text { and cotton blends. There were no } \\
\text { significant differences in antimicrobial } \\
\text { functions against the tested species } \\
\text { between the fabrics used such as } \\
\text { poly/cotton and pure cotton fabrics }\end{array}$ & $\begin{array}{l}\text { The antimicrobial resistance are } \\
\text { generable by regular laundry exposure } \\
\text { to chlorine bleach and can withstand } \\
\text { over } 50 \text { standard machine washes } \\
\text { without deterioration }\end{array}$ & [94] \\
\hline & Cotton & $\begin{array}{l}\text { Staphylococcus aureus } \\
\text { Escherichia coli }\end{array}$ & $\begin{array}{l}\text { The samples possessing amine halamine } \\
\text { structures demonstrated relatively slower } \\
\text { antimicrobial functions than those of the } \\
\text { 1,3-Dimethylol-5,5-dimethylhydantoin } \\
\text { (DMDMH) treated ones }\end{array}$ & $\begin{array}{l}\text { After three cycles of washing, the } \\
\text { sample containing only amine } \\
\text { halamine exhibited the best durability, } \\
\text { whereas the DMDMH-treated fabrics } \\
\text { lost some of the antimicrobial activity } \\
\text { resulting from the loss of the active } \\
\text { imide halamine bonds }\end{array}$ & {$[95]$} \\
\hline
\end{tabular}


Table 3: CONTINUED.

\begin{tabular}{|c|c|c|c|c|c|}
\hline Biocide & Fabric & $\begin{array}{c}\text { Tested } \\
\text { Microorganism }\end{array}$ & Effectiveness & Durability & Reference \\
\hline \multirow[t]{3}{*}{$\begin{array}{l}N \text {-halamine } \\
\text { compounds }\end{array}$} & Cotton & Escherichia coli $\mathrm{K} 12$ & $\begin{array}{l}\text { A 5-logarithmic reduction of Escherichia } \\
\text { coli in a contact time of } 5 \text { to } 15 \text { minutes } \\
\text { makes the acycilic halamine cotton as } \\
\text { powerful as cyclic halamine cotton }\end{array}$ & $\begin{array}{l}\text { The active chlorine contents on } \\
\text { halamine samples did not decrease } \\
\text { after two or three accelerated washes } \\
\text { as compared with one without } \\
\text { accelerated washing. }\end{array}$ & {$[96]$} \\
\hline & $\begin{array}{c}\text { Nomex }{ }^{\circledR}, \\
\text { Kermel and } \\
\text { PBI/Kevlar } \\
\text { synthetic fabric }\end{array}$ & $\begin{array}{l}\text { Staphylococcus aureus } \\
\text { Escherichia coli }\end{array}$ & $\begin{array}{l}\text { The Nomex sample provided } 6 \text { log } \\
\text { reduction to } 10^{6}-10^{7} \mathrm{CFU} / \mathrm{mL} \text { of } \\
\text { Escherichia coli after } 60 \text { minutes of } \\
\text { contact. The Kermel and PBI/Kevlar } \\
\text { samples demonstrated only a } 3 \mathrm{log} \\
\text { reduction, even after } 120 \text { min of contact. } \\
\text { A similar trend is also observed in the } \\
\text { antibacterial tests against } \\
\text { Staphylococcus aureus }\end{array}$ & $\begin{array}{l}\text { After } 10 \text { rounds of bleach/wash } 15 \\
\text { times/bleach cycles, the antibacterial } \\
\text { properties of the samples were } \\
\text { essentially unchanged, indicating that } \\
\text { the antimicrobial properties of the } \\
\text { grafted samples were regenerable. }\end{array}$ & [97] \\
\hline & $\begin{array}{l}\text { Nomex }{ }^{\circledR} \text { and } \\
\text { Kevlar } \\
\text { synthetic fabric }\end{array}$ & $\begin{array}{l}\text { Escherichia coli ATCC } \\
15597 \\
\text { Staphylococcus aureus } \\
\text { ATCC } 6538\end{array}$ & $\begin{array}{l}\text { It can be seen clearly that the fabrics can } \\
\text { provide a total kill of } 10^{6}-10^{7} \mathrm{cfu} / \mathrm{mL} \\
\text { bacteria at a contact time of only } 10 \mathrm{~min}\end{array}$ & $\begin{array}{l}\text { After } 10 \text { washes, few changes can be } \\
\text { detected in their antimicrobial } \\
\text { efficacies. After rebleaching, the } \\
\text { chlorinated fabrics regenerated the } \\
\text { antimicrobial resistance. }\end{array}$ & [98] \\
\hline
\end{tabular}

$\mathrm{NA}=$ Not available 


\section{CONCLUSION AND RECOMMENDATIONS}

Antimicrobial agents imparted onto fabrics play an important role in preventing discomfort and odour and reducing the risk of skin infections caused by fungi and other pathogenic bacteria. However, using triclosan and QACs can cause environmental and health concerns whereas PHMB and $N$-halamine are still good alternatives to impart the antimicrobial properties onto the fabrics. In view of these phenomena and the adverse effect caused by triclosan and QACs, it is recommended that further research should be done to discover new alternatives involving the use of non-toxic ingredients in producing fabric products with potent antimicrobial properties. There should be intensive research on using nanotechnology as a new method to develop antimicrobial fabrics. The development of nanotechnology allows for discovering the antimicrobial properties of metal and metal oxide nanoparticles that can be applied to develop antimicrobial fabrics.

In general, the antimicrobial potency of synthetic antimicrobial agents can be very high compared to natural antimicrobial agents. In fact, synthetic antimicrobial agents can exhibit a wide combination of salient properties compared with natural antimicrobial agents. This is coupled with the fact that the production and application of synthetic antimicrobial agents and antimicrobial fabrics can be highly cost effective. However, there is still the lingering problem of possible human toxicity and possible sacrifice of the environment's integrity. It is therefore recommended that further research should tend towards the use of antimicrobial agents obtained either from plant sources or from microorganisms. Although the efficiency of naturally derived antimicrobial agents is lower compared to synthetic antimicrobial agents at the moment, there is room for improvement. Rigorous research in this area would help to ensure that the next generation of antimicrobial agents are safe to be used for humanrelated applications as well as ecologically friendly.

\section{ACKNOWLEDGEMENT}

The authors would like to thank Universiti Malaysia Pahang for financial support and the Government of Malaysia for providing SLAB scholarship during the study.

\section{REFERENCES}

[1] Akira A. Functional fibers and finishes for humans. Senisha, Inc: Osaka, Japan 1995.

[2] Sun G, Worley SD. (2005) Chemistry of durable and regenerable biocidal textiles. Journal of Chemical Education, 82:60.

[3] Esteban-Cubillo A, Pecharromán C, Aguilar E, Santarén J, Moya JS. (2006) Antibacterial activity of copper monodispersed nanoparticles into sepiolite. J. Materials Science, 41:52085212.

[4] Simoncic B, Tomsic B. (2010) Structures of novel antimicrobial agents for textiles - A review. Textile Research Journal, 80:1721-1737.

[5] Gouveia IC. (2010) Nanobiotechnology: A new strategy to develop non-toxic antimicrobial textiles for healthcare applications. J. Biotechnology, 150:349.

[6] Hammer TR, Mucha H, Hoefer D. (2012) Dermatophyte susceptibility varies towards antimicrobial textiles. Mycoses, 55:344-351.

[7] Song L, Zheng W, Jian-cheng Q, Jin-hui W, Tao T, Li-li H, et al. (2011) One-pot fabrication and antimicrobial properties of novel PET nonwoven fabrics. Biomedical Materials, 6:045009.

[8] Montazer M, Pakdel E, Behzadnia A. (2011) Novel feature of nano-titanium dioxide on textiles: Antifelting and antibacterial wool. J. Applied Polymer Science, 121:3407-3413. 
[9] Balachandra Nair R, Ramachandranna PC. (2010) Patenting of microorganisms: Systems and concerns. J. Commercial Biotechnology 16:337-347.

[10] Zhang Y, Xu Q, Fu F, Liu X. (2016) Durable antimicrobial cotton textiles modified with inorganic nanoparticles. Cellulose, 23:2791-2808.

[11] Yu Q, Wu Z, Chen H. (2015) Dual-function antibacterial surfaces for biomedical applications. Acta Biomaterialia, 16:1-13.

[12] Montazer M, Afjeh MG. (2007) Simultaneous x-linking and antimicrobial finishing of cotton fabric. Journal of Applied Polymer Science, 103:178-185.

[13] Wasif A, Laga S. (2009) Use of nano silver as an antimicrobial agent for cotton. AUTEX Res J, 9:5-13.

[14] Sajitz M, Grohmann J. (2011) Hygiene effects of bleach systems in laundry detergents. SÖFW-Journal, 137.

[15] Zhang S, Yang X, Tang B, Yuan L, Wang K, Liu X, et al. (2018) New insights into synergistic antimicrobial and antifouling cotton fabrics via dually finished with quaternary ammonium salt and zwitterionic sulfobetaine. Chemical Engineering Journal, 336:123-132.

[16] Benn TM, Westerhoff P. (2008) Nanoparticle silver released into water from commercially available sock fabrics. Environmental Science \& Technology, 42:4133-4129.

[17] Percival SL, Bowler PG, Russell D. (2005) Bacterial resistance to silver in wound care. Journal of Hospital Infection, 60:1-7.

[18] Cha J, Lee WB, Park CR, Cho YW, Ahn C-H, Kwon IC. (2006) Preparation and characterization of cisplatin-incorporated chitosan hydrogels, microparticles, and nanoparticles. Macromolecular Research, 14:573-578.

[19] Iyigundogdu ZU, Demir O, Asutay AB, Sahin F. (2017) Developing novel antimicrobial and antiviral textile products. Applied Biochemistry and Biotechnology, 181:1155-1166.

[20] Lim S-H, Hudson SM. (2004) Application of a fiber-reactive chitosan derivative to cotton fabric as an antimicrobial textile finish. Carbohydrate Polymers, 56:227-234.

[21] Yazhini KB, Prabu HG. (2015) Antibacterial activity of cotton coated with $\mathrm{ZnO}$ and ZnOCNT composites. Applied Biochemistry and Biotechnology, 175:85-92.

[22] Gao Y, Cranston R. (2008) Recent advances in antimicrobial treatments of textiles. Textile Research Journal, 78:60-72.

[23] García MT, Ribosa I, Guindulain T, Sánchez-Leal J, Vives-Rego J. (2001) Fate and effect of monoalkyl quaternary ammonium surfactants in the aquatic environment. Environmental Pollution 111:169-175.

[24] Song J, Kong H, Jang J. (2011) Bacterial adhesion inhibition of the quaternary ammonium functionalized silica nanoparticles. Colloids and Surfaces B: Biointerfaces, 82:651-656.

[25] Majumdar P, Lee E, Gubbins N, Stafslien SJ, Daniels J, Thorson CJ, et al. (2009) Synthesis and antimicrobial activity of quaternary ammonium-functionalized POSS (Q-POSS) and polysiloxane coatings containing Q-POSS. Polymer, 50:1124-1133.

[26] Majumdar P, He J, Lee E, Kallam A, Gubbins N, Stafslien SJ, et al. (2010) Antimicrobial activity of polysiloxane coatings containing quaternary ammonium-functionalized polyhedral oligomeric silsesquioxane. J. Coatings Technology and Research, 7:455-467.

[27] McDonnell G, Russell AD. (1999) Antiseptics and disinfectants: activity, action, and resistance. Clinical microbiology reviews, 12:147-179.

[28] Krebs FC, Miller SR, Ferguson ML, Labib M, Rando RF, Wigdahl B. (2005) Polybiguanides, particularly polyethylene hexamethylene biguanide, have activity against human immunodeficiency virus type 1. Biomedicine \& Pharmacotherapy, 59:438-445.

[29] Tang Y, Zhao Y, Wang H, Gao Y, Liu X, Wang X, et al. (2012) Layer-by-layer assembly of antibacterial coating on interbonded 3D fibrous scaffolds and its cytocompatibility assessment. J. Biomedical Materials Research Part A, 100A:2071-2078.

[30] Pinto F, Maillard JY, Denyer SP, McGeechan P. (2010) Polyhexamethylene biguanide exposure leads to viral aggregation. J. Applied Microbiology, 108:1880-1888.

[31] Broxton P, Woodcock PM, Gilbert P. (1983) A study of the antibacterial activity of some polyhexamethylene biguanides towards Escherichia coli ATCC 8739. J. Applied Bacteriology, 54:345-353. 
[32] Ikeda T, Ledwith A, Bamford CH, Hann RA. (1984) Interaction of a polymeric biguanide biocide with phospholipid membranes. Biochimica et Biophysica Acta (BBA) -

Biomembranes, 769:57-66.

[33] Rosin M, Welk A, Kocher T, Majic-Todt A, Kramer A, Pitten FA. (2002) The effect of a polyhexamethylene biguanide mouthrinse compared to an essential oil rinse and a chlorhexidine rinse on bacterial counts and 4-day plaque regrowth. J. Clinical Periodontology, 29:392-399.

[34] Allen MJ, White GF, Morby AP. (2006) The response of Escherichia coli to exposure to the biocide polyhexamethylene biguanide. Microbiology, 152:989-1000.

[35] Lozano N, Rice CP, Ramirez M, Torrents A. (2010) Fate of triclosan in agricultural soils after biosolid applications. Chemosphere, 78:760-766.

[36] Paul KB, Hedge JM, DeVito MJ, Crofton KM. (2010) Short-term exposure to triclosan decreases thyroxine in vivo via upregulation of hepatic catabolism in young Long-Evans Rats. Toxicological Sciences, 113:367-379.

[37] Adolfsson-Erici M, Pettersson M, Parkkonen J, Sturve J. (2002) Triclosan, a commonly used bactericide found in human milk and in the aquatic environment in Sweden. Chemosphere, 46:1485-1489.

[38] Zorrilla LM, Gibson EK, Jeffay SC, Crofton KM, Setzer WR, Cooper RL, et al. (2009) The effects of triclosan on puberty and thyroid hormones in male Wistar rats. Toxicological Sciences 107:56-64.

[39] Levy CW, Roujeinikova A, Sedelnikova S, Baker PJ, Stuitje AR, Slabas AR, et al. (1999) Molecular basis of triclosan activity. Nature, 398:383.

[40] Orhan M, Kut D, Gunesoglu C. (2009) Improving the antibacterial activity of cotton fabrics finished with triclosan by the use of 1,2,3,4-butanetetracarboxylic acid and citric acid. Journal of Applied Polymer Science, 111:1344-1352.

[41] Orhan M, Kut D, Gunesoglu C. (2007) Use of triclosan as antibacterial agent in textiles. J. Fibre and Textile Research, 32:114-118.

[42] Kocer HB, Cerkez I, Worley SD, Broughton RM, Huang TS. (2011) Cellulose/starch/HALS composite fibers extruded from an ionic liquid. Carbohydrate Polymers, 86:922-927.

[43] Worley SD, Williams DE, Crawford RA. (1988) Halamine water disinfectants. Critical Reviews in Environmental Control, 18:133-175.

[44] Chen Z, Sun Y. (2006) N-Halamine-based antimicrobial additives for polymers: Preparation, characterization, and antimicrobial activity. Industrial \& Engineering Chemistry Research, 45:2634-2640.

[45] Kaminski JJ, Bodor N, Higuchi T. (1976) N-halo derivatives III: Stabilization of nitrogenchlorine bond in $N$-chloroamino acid derivatives. J. Pharmaceutical Sciences, 65:553-557.

[46] Braun M, Sun Y. (2004) Antimicrobial polymers containing melamine derivatives. I. Preparation and characterization of chloromelamine-based cellulose. J. Polymer Science Part A: Polymer Chemistry, 42:3818-3827.

[47] Akdag A, Okur S, McKee ML, Worley SD. (2006) The stabilities of N-Cl bonds in biocidal materials. J. Chemical Theory and Computation, 2:879-884.

[48] Windler L, Height M, Nowack B. (2013) Comparative evaluation of antimicrobials for textile applications. Environment International, 53:62-73.

[49] Cheng X, Ma K, Li R, Ren X, Huang TS. (2014) Antimicrobial coating of modified chitosan onto cotton fabrics. Applied Surface Science, 309:138-143.

[50] Ren X, Kocer HB, Worley SD, Broughton RM, Huang TS. (2009) Rechargeable biocidal cellulose: Synthesis and application of 3-(2,3-dihydroxypropyl)-5,5-dimethylimidazolidine2,4-dione. Carbohydrate Polymers, 75:683-687.

[51] Kawabata N, Nishiguchi M. (1988) Antibacterial activity of soluble pyridinium-type polymers. Applied and Environmental Microbiology, 54:2532-2535.

[52] Müller G, Kramer A. (2008) Biocompatibility index of antiseptic agents by parallel assessment of antimicrobial activity and cellular cytotoxicity. J. Antimicrobial Chemotherapy, 61:1281-1287. 
[53] Wiegand C, Abel M, Ruth P, Hipler U-C. (2009) HaCaT keratinocytes in co-culture with Staphylococcus aureus can be protected from bacterial damage by polihexanide. Wound Repair and Regeneration, 17:730-738.

[54] Jones RD, Jampani HB, Newman JL, Lee AS. (2000) Triclosan: A review of effectiveness and safety in health care settings. American Journal of Infection Control, 28:184-196.

[55] Tsao TC, Williams DE, Worley SD. (1990) A new disinfectant compound. Industrial \& Engineering Chemistry Research, 29:2161-2163.

[56] Fu X, Shen Y, Jiang X, Huang D, Yan Y. (2011) Chitosan derivatives with dual-antibacterial functional groups for antimicrobial finishing of cotton fabrics. Carbohydrate Polymers, $85: 221-227$.

[57] $\mathrm{Lu} \mathrm{G}, \mathrm{Wu}$ D, Fu R. (2007) Studies on the synthesis and antibacterial activities of polymeric quaternary ammonium salts from dimethylaminoethyl methacrylate. Reactive and Functional Polymers, 67:355-366.

[58] Du W-L, Niu S-S, Xu Y-L, Xu Z-R, Fan C-L. (2009) Antibacterial activity of chitosan tripolyphosphate nanoparticles loaded with various metal ions. Carbohydrate Polymers, 75:385-389.

[59] Kocer HB, Akdag A, Ren X, Broughton RM, Worley SD, Huang TS. (2008) Effect of alkyl derivatization on several properties of $N$-halamine antimicrobial siloxane coatings. Industrial \& Engineering Chemistry Research, 47:7558-7563.

[60] Li R, Hu P, Ren X, Worley SD, Huang TS. (2013) Antimicrobial $N$-halamine modified chitosan films. Carbohydrate Polymers, 92:534-539.

[61] Gouda M, Ibrahim NA. (2008) New Approach for improving antibacterial functions of cotton fabric. J. Industrial Textiles, 37:327-339.

[62] Docherty KM, Kulpa JCF. (2005) Toxicity and antimicrobial activity of imidazolium and pyridinium ionic liquids. Green Chemistry, 7:185-189.

[63] Rai M, Yadav A, Gade A. (2009) Silver nanoparticles as a new generation of antimicrobials. Biotechnology Advances, 27:76-83.

[64] Joshi M, Ali SW, Purwar R, Rajendran S. (2009) Ecofriendly antimicrobial finishing of textiles using bioactive agents based on natural products.

[65] Grillitsch B, Gans O, Kreuzinger N, Scharf S, Uhl M, Fuerhacker M. (2006) Environmental risk assessment for quaternary ammonium compounds: a case study from Austria. Water Science and Technology, 54:111-118.

[66] Singh R, Jain A, Panwar S, Gupta D, Khare SK. (2005) Antimicrobial activity of some natural dyes. Dyes and Pigments, 66:99-102.

[67] Dastjerdi R, Montazer M. (2010) A review on the application of inorganic nano-structured materials in the modification of textiles: Focus on anti-microbial properties. Colloids and Surfaces B: Biointerfaces, 79:5-18.

[68] Takai K, Ohtsuka T, Senda Y, Nakao M, Yamamoto K, Matsuoka J, et al. (2002) Antibacterial properties of antimicrobial-finished textile products. Microbiology and Immunology 46:75-81.

[69] Kolpin DW, Furlong ET, Meyer MT, Thurman EM, Zaugg SD, Barber LB, et al. (2002) Pharmaceuticals, hormones, and other organic wastewater contaminants in U.S. streams, 1999-2000: A national reconnaissance. Environmental Science \& Technology, 36:12021211.

[70] Singer H, Müller S, Tixier C, Pillonel L. (2002) Triclosan: Occurrence and fate of a widely used biocide in the aquatic environment: Field measurements in wastewater treatment plants, surface waters, and lake sediments. Environmental Science \& Technology, 36:49985004.

[71] Kenawy E-R, Abdel-Hay FI, El-Shanshoury AE-RR, El-Newehy MH. (1998) Biologically active polymers: synthesis and antimicrobial activity of modified glycidyl methacrylate polymers having a quaternary ammonium and phosphonium groups. J. Controlled Release, 50:145-152.

[72] Cakmak I, Ulukanli Z, Tuzcu M, Karabuga S, Genctav K. (2004) Synthesis and characterization of novel antimicrobial cationic polyelectrolytes. European Polymer Journal, 40:2373-2379. 
[73] Bhargava HN, Leonard PA. (1996) Triclosan: Applications and safety. American Journal of Infection Control, 24:209-218.

[74] Dayan AD. (2007) Risk assessment of triclosan [Irgasan $\left.{ }^{\circledR}\right]$ in human breast milk. Food and Chemical Toxicology, 45:125-129.

[75] Hovander L, Malmberg T, Athanasiadou M, Athanassiadis I, Rahm S, Bergman, et al. (2002) Identification of hydroxylated PCB metabolites and other phenolic halogenated pollutants in human blood plasma. Archives of Environmental Contamination and Toxicology, 42:105-17.

[76] Calafat AM, Ye X, Wong L-Y, Reidy JA, Needham LL. (2008) Urinary concentrations of triclosan in the U.S. Population: 2003-2004. Environmental Health Perspectives, 116:303307.

[77] Wolff MS, Teitelbaum SL, Windham G, Pinney SM, Britton JA, Chelimo C, et al. (2007) Pilot study of urinary biomarkers of phytoestrogens, phthalates, and phenols in girls. Environmental Health Perspectives, 115:116-121.

[78] Crofton KM, Paul KB, DeVito MJ, Hedge JM. (2007) Short-term in vivo exposure to the water contaminant triclosan: Evidence for disruption of thyroxine. Environmental Toxicology and Pharmacology, 24:194-197.

[79] Veldhoen N, Skirrow RC, Osachoff H, Wigmore H, Clapson DJ, Gunderson MP, et al. (2006) The bactericidal agent triclosan modulates thyroid hormone-associated gene expression and disrupts postembryonic anuran development. Aquatic Toxicology, 80:217227.

[80] Ioannou CJ, Hanlon GW, Denyer SP. (2007) Action of disinfectant quaternary ammonium compounds against Staphylococcus aureus. Antimicrobial agents and chemotherapy, 51:296-306.

[81] Gaze W, Abdouslam N, Hawkey P, Wellington E. (2005) Incidence of class 1 integrons in a quaternary ammonium compound-polluted environment. Antimicrobial agents and chemotherapy, 49:1802-1807.

[82] McMurry LM, Oethinger M, Levy SB. (1998) Triclosan targets lipid synthesis. Nature, 394:531.

[83] Cerkez I, Worley S, Broughton R, Huang T. (2013) Antimicrobial coatings for polyester and polyester/cotton blends. Progress in Organic Coatings, 76:1082-1087.

[84] Ahmed AESI, Wardell JN, Thumser AE, Avignone-Rossa CA, Cavalli G, Hay JN, Bushell ME. (2011) Metabolomic profiling can differentiate between bactericidal effects of free and polymer bound halogen. J. Applied Polymer Science, 119:709-718.

[85] Li Z, Chen J, Cao W, Wei D, Zheng A, Guan Y. (2018) Permanent antimicrobial cotton fabrics obtained by surface treatment with modified guanidine. Carbohydrate polymers, 180:192-199.

[86] Son Y-A, Kim B-S, Ravikumar K, Lee S-G. (2006) Imparting durable antimicrobial properties to cotton fabrics using quaternary ammonium salts through 4aminobenzenesulfonic acid-chloro-triazine adduct. European Polymer Journal, 42:30593067.

[87] Diz M, Infante MR, Erra P, Manresa A. (2001) Antimicrobial activity of wool treated with a new thiol cationic surfactant. Textile Research Journal, 71:695-700.

[88] Kim HW, Kim BR, Rhee YH. (2010) Imparting durable antimicrobial properties to cotton fabrics using alginate-quaternary ammonium complex nanoparticles. Carbohydrate Polymers, 79:1057-1062.

[89] Kim YH, Sun G. (2001) Durable antimicrobial finishing of nylon fabrics with acid dyes and a quaternary ammonium salt. Textile Research Journal, 71:318-323.

[90] Zhu P, Sun G. (2004) Antimicrobial finishing of wool fabrics using quaternary ammonium salts. Journal of Applied Polymer Science, 93:1037-1041.

[91] Kawabata A, Taylor JA. (2007) The effect of reactive dyes upon the uptake and antibacterial efficacy of poly(hexamethylene biguanide) on cotton. Part 3: Reduction in the antibacterial efficacy of poly(hexamethylene biguanide) on cotton, dyed with bis(monochlorotriazinyl) reactive dyes. Carbohydrate Polymers, 67:375-389. 
[92] Goetzendorf-Grabowska B, Królikowska H, Gadzinowski M. (2004) Polymer microspheres as carriers of antibacterial properties of textiles: a preliminary study. Fibres \& Textiles in Eastern Europe, 12:62-64.

[93] Lu J, Hill MA, Hood M, Greeson DF, Horton JR, Orndorff PE, et al. (2001) Formation of antibiotic, biodegradable polymers by processing with Irgasan DP300R (triclosan) and its inclusion compound with $\beta$-cyclodextrin. J. Applied Polymer Science, 82:300-309.

[94] Sun Y, Sun G. (2001) Novel regenerable $N$-halamine polymeric biocides. III. Grafting hydantoin-containing monomers onto synthetic fabrics. J. Applied Polymer Science, 81:1517-1525.

[95] Qian L, Sun G. (2004) Durable and regenerable antimicrobial textiles: Improving efficacy and durability of biocidal functions. J. Applied Polymer Science, 91:2588-2593.

[96] Liu S, Sun G. (2006) Durable and regenerable biocidal polymers: Acyclic $N$-halamine cotton cellulose. Industrial \& Engineering Chemistry Research, 45:6477-6482.

[97] Sun Y, Sun G. (2003) Novel refreshable $N$-halamine polymeric biocides: Grafting hydantoin-containing monomers onto high performance fibers by a continuous process. Journal of Applied Polymer Science, 88:1032-1039.

[98] Sun Y, Sun G. (2004) Novel refreshable $N$-halamine polymeric biocides: $N$-chlorination of aromatic polyamides. Industrial \& Engineering Chemistry Research, 43:5015-5020.

[99] Kasiri MB, Safapour S. (2014) Natural dyes and antimicrobials for green treatment of textiles. Environmental Chemistry Letters, 12:1-13.

[100] Kasiri MB, Khataee AR. (2011) Photooxidative decolorization of two organic dyes with different chemical structures by $\mathrm{UV} / \mathrm{H}_{2} \mathrm{O}_{2}$ process: Experimental design. Desalination, 270:151-159.

[101] Kasiri MB, Aleboyeh H, Aleboyeh A. (2008) Degradation of Acid Blue 74 using Fe-ZSM5 zeolite as a heterogeneous photo-Fenton catalyst. Applied Catalysis B: Environmental, 84:915.

[102] Safapour S, Seyed-Esfahani M, Auriemma F, Ruiz de Ballesteros O, Vollaro P, Di Girolamo $\mathrm{R}$, et al. (2010) Reactive blending as a tool for obtaining poly(ethylene terephthalate)-based engineering materials with tailored properties. Polymer, 51:4340-4350.

[103] Sivakumar V, Vijaeeswarri J, Anna JL. (2011) Effective natural dye extraction from different plant materials using ultrasound. Industrial Crops and Products, 33:116-122.

[104] Chen Q, Shen X, Gao H. (2006) One-step synthesis of silver-poly(4-vinylpyridine) hybrid microgels by $\gamma$-irradiation and surfactant-free emulsion polymerisation. The photoluminescence characteristics. Colloids and Surfaces A: Physicochemical and Engineering Aspects, 275:45-9.

[105] Joshi M, Ali SW, Rajendran S. (2007) Antibacterial finishing of polyester/cotton blend fabrics using neem (Azadirachta indica): A natural bioactive agent. Journal of Applied Polymer Science, 106:793-800.

[106] Haufe H, Muschter K, Siegert J, Böttcher H. (2008) Bioactive textiles by sol-gel immobilised natural active agents. J. Sol-Gel Science and Technology, 45:97-101.

[107] Boh B, Knez E. (2006) Microencapsulation of essential oils and phase change materials for applications in textile products.

[108] Subramani K, Murugan V, Kolathupalayam Shanmugam B, Rangaraj S, Palanisamy M, Venkatachalam R, et al. (2017) An ecofriendly route to enhance the antibacterial and textural properties of cotton fabrics using herbal nanoparticles from Azadirachta indica (neem). J. Alloys and Compounds, 723:698-707.

[109] Selvam RM, Athinarayanan G, Nanthini AUR, Singh AJAR, Kalirajan K, Selvakumar PM. (2015) Extraction of natural dyes from Curcuma longa, Trigonella foenum graecum and Nerium oleander, plants and their application in antimicrobial fabric. Industrial Crops and Products, 70:84-90.

[110] Pinho E, Henriques M, Oliveira R, Dias A, Soares G. (2010) Development of biofunctional textiles by the application of resveratrol to cotton, bamboo, and silk. Fibers and Polymers, $11: 271-276$. 